\title{
TO STUDY THE RELATIONSHIP BETWEEN SERUM TESTOSTERONE, HSCRP AND CAROTID ATHEROSCLEROSIS IN MEN FROM NORTHWEST PUNJAB WITH TYPE 2 DIABETES MELLITUS
}

\author{
${ }^{1}$ Associate Professor, Department of Medicine, Government Medical College, Amritsar. \\ 2Junior Resident, Department of Medicine, Government Medical College, Amritsar. \\ ${ }_{3}^{3}$ Assistant Professor, Department of Medicine, Government Medical College, Amritsar. \\ ${ }^{4}$ Junior Resident, Department of Medicine, Government Medical College, Amritsar. \\ 5 Junior Resident, Department of Medicine, Government Medical College, Amritsar. \\ 6Junior Resident, Department of Medicine, Government Medical College, Amritsar. \\ 7 Junior Resident, Department of Medicine, Government Medical College, Amritsar. \\ 8 Junior Resident, Department of Medicine, Government Medical College, Amritsar.
}

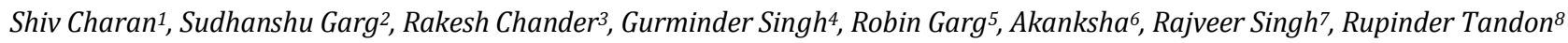

\section{ABSTRACT}

\section{BACKGROUND}

The average life expectancy of Women is at least five years more than Men across all age groups and in most nations. Traditionally, this difference has been attributed to the protective role played by Oestrogen in Women. However, the role of Serum Testosterone has not yet been as extensively evaluated. Initially it was believed that serum testosterone has no protective role but recent studies have provided evidence contrary to that assumption.

The objective is to study the relationship between Serum hsCRP, Testosterone and Carotid Atherosclerosis in Men with Type 2 Diabetes Mellitus.

\section{MATERIALS AND METHODS}

We randomly assessed 100 patients of type 2 Diabetes Mellitus attending various OPDs and wards of the hospital for levels of Serum Testosterone. We then proceeded to compare the various atherosclerotic markers between the two groups (with normal Serum Testosterone vs. Low Serum Testosterone). The results were then statistically analysed.

\section{RESULTS}

Prevalence of Low Serum Testosterone was $34 \%$ in our study. A higher BMI $\left(28+/-2.5 \mathrm{~kg} / \mathrm{m}^{2}\right)$ seen in the Low Serum Testosterone group versus the normal Testosterone group $\left(25.9+/-2.61 \mathrm{~kg} / \mathrm{m}^{2}\right)$. Increased Serum Cholesterol seen in the Low Serum Testosterone group $(191.6+/-50.5 \mathrm{mg} / \mathrm{dL})$ versus the normal Serum Testosterone $(172+/-39.1 \mathrm{mg} / \mathrm{dL})$ group. Raised Triglycerides seen in the Low Serum Testosterone group $(157.1+/-58.7 \mathrm{mg} / \mathrm{dL})$ than the normal Serum Testosterone group $(137.6+/-31.9 \mathrm{mg} / \mathrm{dL})$. Non-HDL Cholesterol in the Low Serum Testosterone group $(155.2+/-49.1 \mathrm{mg} / \mathrm{dL})$ was higher compared to the normal Testosterone Group $(134.4+/-38 \mathrm{mg} / \mathrm{dL})$. HbA1c levels were marginally higher in the Low Serum Testosterone group $(7.9+/-1.1 \%)$ when compared to the normal Testosterone Group (7.5 +/- 0.9\%). Increased hsCRP levels were seen in the Low Serum Testosterone group $(3.2+/-1.0 \mathrm{mg} / \mathrm{dL})$ than in the normal Testosterone Group (1.9+/- $0.8 \mathrm{mg} / \mathrm{dL})$. CIMT in the Low Serum Testosterone group $(0.82+/-0.1 \mathrm{~mm})$ was significantly more than the normal Testosterone Group (0.65 +/- $0.1 \mathrm{~mm})$. IHD was more frequent in the Low Serum Testosterone group (29\%) versus the normal Testosterone Group (20\%).

\section{CONCLUSION}

To conclude, a Low Serum Testosterone can serve as an adverse prognostic marker contributing to an increased atherosclerotic burden. Serum Testosterone should be screened for in all newly diagnosed patients of Type 2 Diabetes Mellitus.

\section{KEYWORDS}

CIMT, Intima Media Thickness, HbA1c, Ischaemic Heart Disease, Cerebrovascular Accident.

HOW TO CITE THIS ARTICLE: Charan S, Garg S, Chander R, et al. To study the relationship between serum testosterone, hsCRP and carotid atherosclerosis in men from northwest Punjab with Type 2 diabetes mellitus. J. Evolution Med. Dent. Sci. 2017;6(23): 1872-1876, DOI: $10.14260 / J e m d s / 2017 / 411$

\section{BACKGROUND}

The average life expectancy of Women is at least five years more than Men across all age groups and in most nations.

Financial or Other, Competing Interest: None.

Submission 27-02-2017, Peer Review 10-03-2017,

Acceptance 13-03-2017, Published 20-03-2017.

Corresponding Author:

Dr. Sudhanshu Garg,

E-15/154,

Sector-8,

Rohini, Delhi -110085.

E-mail: sudhanshugarg90@gmail.com

DOI: $10.14260 /$ jemds $/ 2017 / 411$

\section{(c) $($ ) $९$}

Traditionally, this difference has been attributed to the protective role played by Oestrogen in Women. However, the role of Serum Testosterone has not yet been as extensively evaluated. Initially it was believed that serum testosterone has no protective role, but recent studies have provided evidence contrary to that assumption.

\section{Aims and Objectives \\ To study the relationship between Serum hsCRP, Testosterone and Carotid Atherosclerosis in Men with Type 2 Diabetes Mellitus.}

\section{MATERIALS AND METHODS}

The present study was conducted in 100 cases attending various OPD/ Indoor admissions of Guru Nanak Dev Hospital, 
Amritsar and allied group of hospitals attached to Government Medical College, Amritsar after obtaining an informed consent. Diagnosis of Diabetes was made as per American Diabetes Association criteria 2014.(1) Detailed history and thorough physical examination were done. Routine investigations like Haemoglobin, TLC, DLC, Urea, Creatinine, S. Bilirubin, SGOT, SGPT, Total Serum Protein, Serum Albumin, HbA1c, Lipid Profile, ECG, Fasting and Random Blood Sugar were done. Serum hsCRP was measured by Quantia CRP US. It is a turbidimetric immunoassay for ultrasensitive determination of C-Reactive protein based on the process of latex agglutination.(2) Serum Testosterone was measured using Testosterone ELISA ALPCO kit for quantitative determination. (3)

Blood pressure measurements were obtained after minimum 5 minutes of rest in supine or semi-recumbent position and value obtained to the nearest $2 \mathrm{~mm}$ of mercury mark. Measurements for testosterone were obtained after overnight fasting, venous sample was obtained between 8:00 a.m. to 11:00 a.m. and stored at $4^{\circ} \mathrm{C}$. Test for HbA1c, lipid profile, and serum C-reactive protein was performed. Carotid Doppler was used to measure degree of intimal thickness.

\section{Inclusion Criteria}

- Diabetes Mellitus type 2 patients.

- Male patient.

- Positive screening questionnaire for androgen deficiency.

\section{Exclusion Criteria}

- Diabetes mellitus type 1.

- Female patient.

- Renal or hepatic disease, infarction, systemic inflammation and infection.

- Secondary hypogonadism.

- Treatment by testosterone or testosterone replacement therapy 3 months prior to therapy.

- ACS/Stroke/TIA in last 3 months.

Carotid Doppler ultrasonography was performed by a single operator and the CIMT was measured using B-mode ultrasound and a $7.5 \mathrm{MHz}$ transducer. Intimal-medial thickness was defined as the distance between the leading edge of the first echogenic line (lumen-intima interface) and the second echogenic line (media-adventitia interface) of the far wall. Three measurements were taken at $0.5,1$ and $2 \mathrm{~cm}$ below the carotid bifurcation of the common carotid artery on each side, and their arithmetic averages were calculated. The intimal-medial thickness of both sides (right and left) was also calculated and the average of these two values was calculated. In this study, an atherosclerotic plaque is defined as a local thickness of intima greater than $1 \mathrm{~mm}$ or two times more than its adjacent normal layer.

\section{Sample Size Estimation}

On basis of the results of the study done by El. Saghier EO et al ${ }^{4}$ taking alpha error as 0.5 power analysis was done and sample size was estimated to be 100 .

\section{Statistical Analysis}

Simple random sampling was done. The statistical software SPSS (Statistical package for Social Sciences) Ver. 21 was used for statistical analysis. The mean \pm standard deviation was calculated. Pair-wise comparison between the cases and controls was performed for all parameters using Student's
Unpaired t-test. The values of $\mathrm{P}<0.05$ were considered as significant. The qualitative variables were compared using the chi-square test.

\section{RESULTS}

The present study was undertaken to evaluate the relation between Serum Testosterone, hsCRP and Carotid atherosclerosis in patients of Diabetes Mellitus in North West Punjabi population. In the present study, 100 patients with Diabetes Mellitus were taken from the various OPD/Indoor Admissions from Guru Nanak Dev Hospital after taking informed consent. Detailed history was taken and general and systemic examination was done. These patients were then systematically tested and the results were statistically analysed.

The mean age of the population under study was 60.17 years with a standard deviation of 13.23 years and a minimum of 23 to a maximum of 86 years. Mean duration of Diabetes of the population was 6 years.

\begin{tabular}{|c|c|}
\hline Age Group & Number \\
\hline $21-30$ & 3 \\
\hline $31-40$ & 6 \\
\hline $41-50$ & 14 \\
\hline $51-60$ & 27 \\
\hline $61-70$ & 35 \\
\hline $71-80$ & 11 \\
\hline $81-90$ & 4 \\
\hline \multicolumn{2}{|c|}{ Table 1. Age Distribution } \\
\hline
\end{tabular}

The population under study was divided into two groups on basis of levels of Serum Testosterone. The Age difference between the two groups was not statistically significant.

Low Serum Testosterone was found in $34 \%$ of the population.

\section{BMI and Serum Testosterone}

The mean BMI was $26.6+/-2.75 \mathrm{~kg} / \mathrm{m}^{2}$ with a minimum of $20.1 \mathrm{~kg} / \mathrm{m}^{2}$ and maximum of $34.5 \mathrm{~kg} / \mathrm{m}^{2}$.

The BMI of Low Testosterone group was significantly higher $\left(28 \mathrm{~kg} / \mathrm{m}^{2}\right)$ than the normal Testosterone group (25.9 $\left.\mathrm{kg} / \mathrm{m}^{2}\right)$.

\begin{tabular}{|c|l|c|}
\hline $\begin{array}{c}\text { Serum Testosterone } \\
(\mathbf{n m o l} / \mathrm{L})\end{array}$ & \multicolumn{1}{|c|}{$>\mathbf{8}$} & $>\mathbf{8}$ \\
\hline $\mathrm{BMI}\left(\mathrm{kg} / \mathrm{m}^{2}\right)$ & $28.0(\mathrm{SD}=2.50)$ & $25.9(\mathrm{SD}=2.61)$ \\
\hline $\mathrm{P}$-value & \multicolumn{2}{|c|}{$<0.01$} \\
\hline \multicolumn{3}{|c}{ Table 2} \\
\hline
\end{tabular}

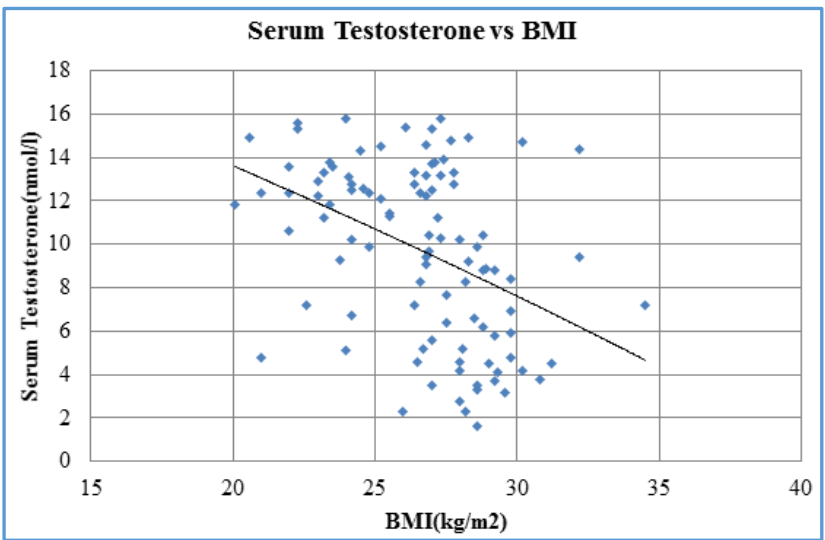




\section{Mean Cholesterol (CHO) and Serum Testosterone}

Mean Cholesterol was $179 \mathrm{mg} / \mathrm{dL}$ with a standard deviation of $44 \mathrm{mg} / \mathrm{dL}$ with a minimum of 96 and a maximum of 290 $\mathrm{mg} / \mathrm{dL}$. As given in Table No.3, the Mean Cholesterol in the Low Serum Testosterone group $(191.6+/-50.5 \mathrm{mg} / \mathrm{dL})$ was significantly higher than the normal Serum Testosterone group $(172.8+/-39.1 \mathrm{mg} / \mathrm{dL})$. This suggests an increased mean Cholesterol with lower serum Testosterone levels.

\begin{tabular}{|c|c|c|}
\hline $\begin{array}{c}\text { Serum Testosterone } \\
\text { (nmol/L) }\end{array}$ & $\mathbf{< 8}$ & $>\mathbf{8}$ \\
\hline $\begin{array}{c}\text { Mean Cholesterol } \\
(\mathrm{mg} / \mathrm{dL})\end{array}$ & $\begin{array}{c}191.6 \\
(\mathrm{SD}=50.5)\end{array}$ & $\begin{array}{c}172.8 \\
(\mathrm{SD}=39.1)\end{array}$ \\
\hline P-value & \multicolumn{2}{|c|}{0.04} \\
\hline \multicolumn{2}{|c}{} \\
\hline
\end{tabular}

\section{Serum Triglyceride levels and Serum Testosterone}

Mean Serum Triglyceride of the population was $144.23+/$ $43.6 \mathrm{mg} / \mathrm{dL}$ with a minimum of 96 . The mean Serum Triglyceride in the Low Serum Testosterone group (157 +/$58.7 \mathrm{mg} / \mathrm{dL}$ ) was more than the normal Serum Testosterone group $(137.6+/-31.9 \mathrm{mg} / \mathrm{dL})$ indicating worse triglyceride profile in patients with lower levels of Total Serum Testosterone (shown in table no. 4).

\begin{tabular}{|c|c|c|}
\hline $\begin{array}{c}\text { Serum Testosterone } \\
(\mathbf{n m o l} / \mathrm{L})\end{array}$ & $<\mathbf{8}$ & $\mathbf{8}$ \\
\hline $\mathrm{TG}(\mathrm{mg} / \mathrm{dL})$ & $\begin{array}{c}157 \\
(\mathrm{SD}=58.7)\end{array}$ & $\begin{array}{c}137.6 \\
(\mathrm{SD}=31.9)\end{array}$ \\
\hline P-value & \multicolumn{2}{|c|}{0.03} \\
\hline \multicolumn{2}{|c}{ Table 4 } \\
\hline
\end{tabular}

\section{Serum Testosterone and Serum HDL}

Mean Serum HDL of the group was $37.7 \mathrm{mg} / \mathrm{dL}$ with SD of 7.3 $\mathrm{mg} / \mathrm{dL}$. The Serum HDL in low Testosterone group was 36.4 $\mathrm{mg} / \mathrm{dL}$ and in normal Serum Testosterone group was 38.4 $\mathrm{mg} / \mathrm{dL}$. The difference was not statistically significant as shown in the Table No. 5.

\begin{tabular}{|c|c|c|}
\hline $\begin{array}{c}\text { Serum Testosterone } \\
\text { (nmol/L) }\end{array}$ & $<8$ & $>\mathbf{8}$ \\
\hline Serum HDL (mg/dL) & $36.38(\mathrm{SD}=8.0)$ & $38.41(\mathrm{SD}=6.9)$ \\
\hline P-value & \multicolumn{2}{|c|}{0.214} \\
\hline \multicolumn{3}{|c|}{ Table 5 } \\
\hline
\end{tabular}

Serum Non-HDL Cholesterol (Non-HDL CHO) and Serum Testosterone

Mean Non-HDL Cholesterol levels were $141.4 \mathrm{mg} / \mathrm{dL}$ with a standard deviation of $43 \mathrm{mg} / \mathrm{dL}$. The mean Non-HDL in Low Testosterone group was $155.2 \mathrm{mg} / \mathrm{dL}$ while in the normal Testosterone group was $134 \mathrm{mg} / \mathrm{dL}$ as shown in Table No. 6 . This suggests a higher dyslipidaemia burden in patients with lowered serum Testosterone.

\begin{tabular}{|c|c|c|}
\hline $\begin{array}{c}\text { Serum Testosterone } \\
\text { (nmol/L) }\end{array}$ & $\mathbf{<}$ & $>\mathbf{8}$ \\
\hline $\begin{array}{c}\text { Non-HDL Cholesterol } \\
\text { (mg/dL) }\end{array}$ & $155.2(\mathrm{SD}=49.1)$ & $134.4(\mathrm{SD}=38.0)$ \\
\hline P-value & \multicolumn{2}{|c|}{0.02} \\
\hline \multicolumn{3}{|l}{ Table 6 } \\
\hline
\end{tabular}

\section{Serum hsCRP and Serum Testosterone}

Mean serum hsCRP of the population was $2.35 \mathrm{ng} / \mathrm{mL}$ with a SD of $1.09 \mathrm{ng} / \mathrm{mL}$. The hsCRP levels among the low Serum Testosterone group was $3.2 \mathrm{ng} / \mathrm{mL}$ and in the normal Testosterone group was $1.9 \mathrm{ng} / \mathrm{mL}$ (shown in Table no. 7). The difference was statistically significant indicating higher vascular inflammation in patients with lowered serum Testosterone.

\begin{tabular}{|c|c|c|}
\hline Serum Testosterone (nmol/L) & $<\mathbf{8}$ & $>\mathbf{8}$ \\
\hline hsCRP (mg/dL) & $3.2(\mathrm{SD}=1.0)$ & $1.9(\mathrm{SD}=0.8)$ \\
\hline P-value & \multicolumn{2}{|c|}{$<0.001$} \\
\hline \multicolumn{2}{|c|}{ Table 7 } \\
\hline
\end{tabular}

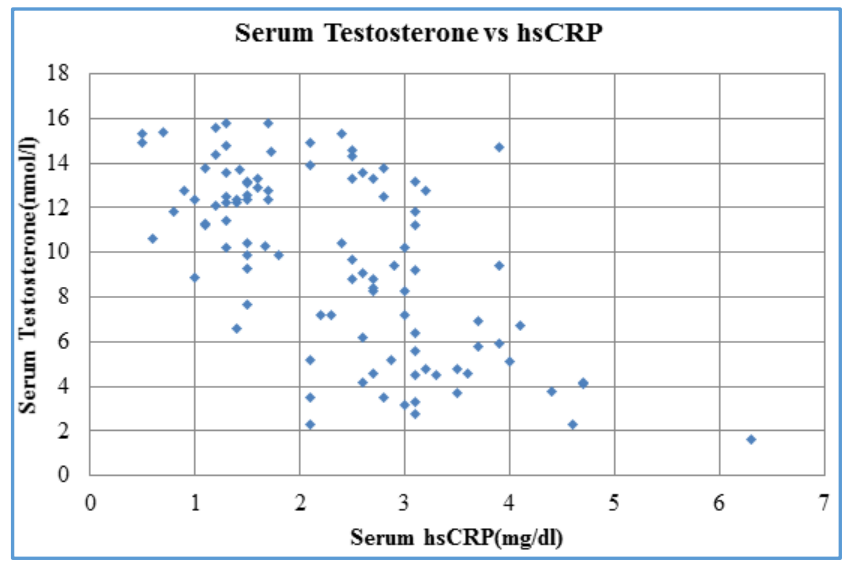

\section{CIMT and Serum Testosterone}

Mean CIMT of the population was $0.71 \mathrm{~mm}$ with a standard deviation of $0.12 \mathrm{~mm}$ as displayed in Table No. 8, the CIMT of the low Testosterone group was $0.82 \mathrm{~mm}$ and of normal Testosterone group was $0.68 \mathrm{~mm}$. The difference was statistically significant. This suggests increased atherosclerosis in patients with lower Total Testosterone levels.

\begin{tabular}{|c|c|c|}
\hline Serum Testosterone (nmol/L) & $<\mathbf{8}$ & $>\mathbf{8}$ \\
\hline \multirow{2}{*}{ CIMT (mm) } & $0.82 \mathrm{~mm}$ & $0.65 \mathrm{~mm}$ \\
& $(\mathrm{SD}=0.1 \mathrm{~mm})$ & $(\mathrm{SD}=0.1 \mathrm{~mm})$ \\
\hline P-value & \multicolumn{2}{|c|}{$<0.001$} \\
\hline \multicolumn{2}{|c|}{ Table 8} \\
\hline
\end{tabular}

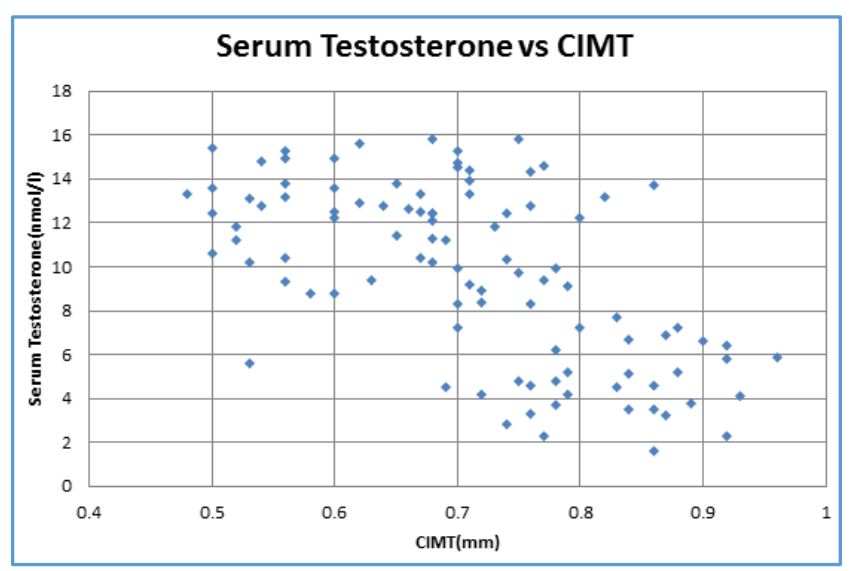

Prevalence of IHD and Serum Testosterone

IHD occurred in $29 \%$ of cases with low Serum Testosterone and $19 \%$ of cases with normal serum Testosterone (Table No. 
9). A lower serum Testosterone was associated with 1.5 times more frequent incidence of IHD.

\begin{tabular}{|c|c|c|}
\hline Serum Testosterone (nmol/L) & $<\mathbf{8}$ & $>\mathbf{8}$ \\
\hline Individuals without IHD & 24 & 53 \\
\hline IHD & 10 & 13 \\
\hline P-value & \multicolumn{2}{|c|}{0.001} \\
\hline Table 9
\end{tabular}

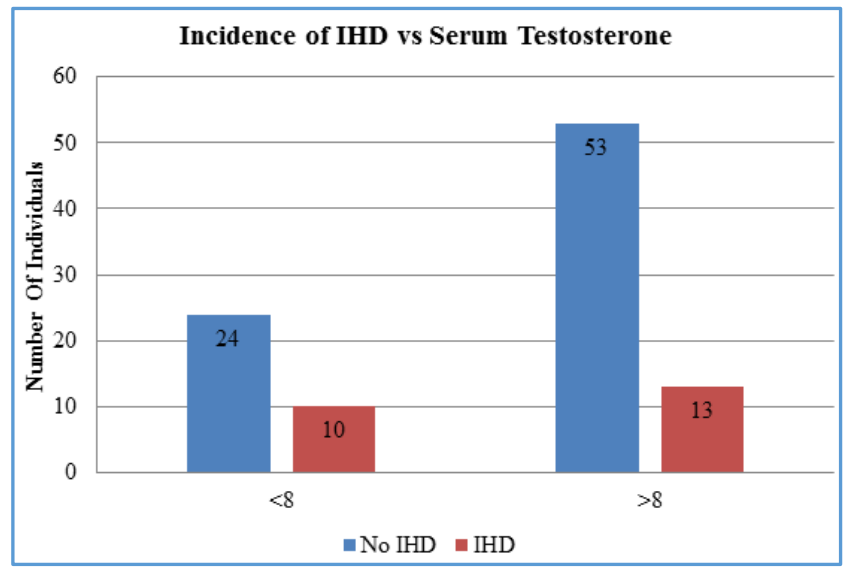

\section{HbA1c and Serum Testosterone}

Mean HbA1c of the population was $7.63 \%$ with a SD of $+/-$ $0.99 \%$. HbA1c in the low Testosterone group was $7.9+/$ $1.1 \%$ whereas in the normal Testosterone group was $7.5+/$ $0.9 \%$ indicating a worse glycaemic control in patients with low serum Testosterone. The same has been depicted in Table No.10.

\begin{tabular}{|c|c|c|}
\hline Serum Testosterone (nmol/L) & $<\mathbf{8}$ & $>\mathbf{8}$ \\
\hline HbA1c (\%) & $7.9(\mathrm{SD}=1.1)$ & $7.5(\mathrm{SD}=0.9)$ \\
\hline P-value & \multicolumn{2}{|c|}{0.048} \\
\hline \multicolumn{2}{|c|}{ Table 10 } \\
\hline
\end{tabular}

\section{DISCUSSION}

In our study, we found that a low serum testosterone is more prevalent among diabetics than the general population. We used a criterion of Serum Testosterone $<8 \mathrm{ng} / \mathrm{mL}$ as our cutoff. A similar finding was noted by Barrett-Connor E,(5) $\mathrm{Al}$ Hayek AA,(6) Kapoor D,(7) and Ayman A. Al Hayek et al.(8)

\section{Testosterone and BMI}

The BMI was found to range from $20.1 \mathrm{~kg} / \mathrm{m}^{2}$ to $34.5 \mathrm{~kg} / \mathrm{m}^{2}$ with a mean of $26.6+/-2.75 \mathrm{~kg} / \mathrm{m}^{2}$. The BMI of the low Testosterone group was $28.0+/-2.5 \mathrm{~kg} / \mathrm{m}^{2}$ and that of the normal Serum Testosterone group was $25.89+/-2.6 \mathrm{~kg} / \mathrm{m}^{2}$. In the study conducted by W.E. Roudebush et al(9) (done on healthy adult males in 2005), the mean serum Testosterone was $19.6 \mathrm{nmol} / \mathrm{L}$ in Normal weight (BMI < 25), $14.9 \mathrm{nmol} / \mathrm{L}$ in overweight (BMI 25 to 29.9) and $14.4 \mathrm{nmol} / \mathrm{L}$ in obese (BMI more than 30 ).

\section{Testosterone and Dyslipidaemia}

The Mean Cholesterol of the study group was found to be $179.2+/-43.95 \mathrm{mg} / \mathrm{dL}$. Mean cholesterol of the low serum testosterone group was $191.6+/-50.5 \mathrm{mg} / \mathrm{dL}$ and in the normal testosterone group was $172.8+/-39.1 \mathrm{mg} / \mathrm{dL}$. Mean triglyceride levels of the total population were $144.2+/-43.7$ $\mathrm{mg} / \mathrm{dL}$. Mean triglyceride of the low testosterone group was
$157.1+/-58.7 \mathrm{mg} / \mathrm{dL}$ and in the normal testosterone group was $137.6+/-31.9 \mathrm{mg} / \mathrm{dL}$. Mean Non-HDL of the population was $141.4+/-43.0 \mathrm{mg} / \mathrm{dL}$. Mean Non-HDL in the low testosterone group was $155.2+/-49.1 \mathrm{mg} / \mathrm{dL}$ and in the normal Testosterone group was $134.4+/-38.0 \mathrm{mg} / \mathrm{dL}$. In the study done by Simon D. et al(10) patients who had lower Serum Testosterone levels had increased serum Triglycerides (1.35 vs. $1.0 \mathrm{mmol} / \mathrm{L}$ ), increased Total Cholesterol, increased LDL and decreased HDL cholesterol.

\section{Testosterone and hsCRP}

The mean hsCRP of the population under study was $2.35+/$ $1.09 \mathrm{mg} / \mathrm{dL}$ with a maximum of $6.3 \mathrm{mg} / \mathrm{dL}$ and a minimum of $0.5 \mathrm{mg} / \mathrm{dL}$. Mean hsCRP of the low testosterone group was $3.2+/-1.0 \mathrm{mg} / \mathrm{dL}$ and of normal testosterone group was 1.9 $+/-0.9 \mathrm{mg} / \mathrm{dL}$. In the study performed by Gannagé-Yared et al,(11) they studied 201 men and found that Total Testosterone was inversely associated with serum hsCRP and BMI. The study of Schneider HJ et al(12) concluded that obesity, metabolic syndrome, and acute inflammation was associated with hypogonadal testosterone levels. In the study by Javier M. F. et al,(13) hsCRP levels were $2.74+/-1.37 \mathrm{mg} / \mathrm{dL}$ in low serum $\mathrm{T}$ group and $0.89+/-0.93 \mathrm{mg} / \mathrm{dL}$ in the normal Serum $\mathrm{T}$ group.

\section{Testosterone with CIMT}

The CIMT was found to range from $0.48 \mathrm{~mm}$ to $0.96 \mathrm{~mm}$ with a mean of $0.71 \mathrm{~mm}+/-0.12 \mathrm{~mm}$. The CIMT of low Serum Testosterone group was $0.82+/-0.1 \mathrm{~mm}$ and of Normal Serum Testosterone group was $0.65+/-0.1 \mathrm{~mm}(\mathrm{p}<0.05)$. In the study performed by Javier M.F. et al, they studied the effect of low Serum Testosterone $(<12 \mathrm{nmol} / \mathrm{L})$ on CIMT. On multiple logistic regression analysis, they found that a lower level of Serum Testosterone was independently associated with a greater IMT but not with atherosclerotic plaque. In the study done by Soisson V. et al,(14) they found that among men with low grade inflammation (CRP $>2 \mathrm{mg} / \mathrm{dL}$ ), mean IMT was higher in subjects with bioavailable Testosterone $<3.2 \mathrm{ng} / \mathrm{mL}$ than those with Testosterone $>3.2 \mathrm{ng} / \mathrm{mL}$.

\section{Testosterone vs. IHD}

IHD was present in 23 cases. IHD prevalence was $29 \%$ in Low Testosterone group and $19.7 \%$ in normal testosterone group. In the study performed by English K.M. et al,(15) a statistically significant association was seen between incidence of IHD and baseline Serum Testosterone levels. The study conducted by Jones RD et al(16) also concluded that a lower Serum Testosterone is associated with a higher incidence of Coronary Artery Disease. Rosano GM et al(17) evaluated 129 male patients out of which 119 had proven CAD. In their study, patients of CAD had significantly lower levels of Testosterone compared to controls $(9.8+/-6.5$ vs. $13.5+/-$ $5.4 \mathrm{nmol} / \mathrm{L}$ ). They also found an inverse relation between cases with one vessel, two vessel and triple vessel disease and serum Testosterone levels. In a prospective population based study by Laughlin GA et al(18) on 794 men aged 50 to 91 years, they found a higher mortality in men whose testosterone levels were in the lowest quartile.

\section{Testosterone vs. HbA1c}

$\mathrm{HbA1c}$ was found to range from $5.6 \%$ to $10.7 \%$ with a mean of $7.6+/-1.0 \%$. In the low Serum Testosterone group, HbA1c 
was $7.9 \%$ and in the normal Serum Testosterone group HbA1c was $7.5 \%$. The difference was small but statistically significant. In the study conducted by Hackett et al,(19) HbA1c was $7.8 \%$ in low Serum Testosterone group and $7.2 \%$ in normal Serum Testosterone group. In the study done by Prajeesh Kurup et al, they found that increase of HbA1c and Fasting plasma glucose correlated negatively with Serum Testosterone levels. A study by Fukui $\mathrm{M}$ et al(20) also found the ratio of $\mathrm{HbA1c}$ vs. bioavailable testosterone as $2.94+/$ 0.38 . They concluded a negative correlation exists between the same.

\section{CONCLUSION}

\section{Summary}

Prevalence of Low Serum Testosterone was 34\% in our study. A higher BMI $\left(28+/-2.5 \mathrm{~kg} / \mathrm{m}^{2}\right)$ seen in the Low Serum Testosterone group versus the normal Testosterone group $\left(25.9+/-2.61 \mathrm{~kg} / \mathrm{m}^{2}\right)$. Increased Serum Cholesterol seen in the Low Serum Testosterone group (191.6 +/- 50.5 $\mathrm{mg} / \mathrm{dL})$ versus the normal Serum Testosterone $(172+/-39.1$ $\mathrm{mg} / \mathrm{dL}$ ) group. Raised Triglycerides seen in the Low Serum Testosterone group $(157.1+/-58.7 \mathrm{mg} / \mathrm{dL})$ than the normal Serum Testosterone group $(137.6+/-31.9 \mathrm{mg} / \mathrm{dL})$. Non-HDL Cholesterol in the Low Serum Testosterone group (155.2 +/$49.1 \mathrm{mg} / \mathrm{dL}$ ) was higher compared to the normal Testosterone Group (134.4 +/- 38 mg/dL). HbA1c levels were marginally higher in the Low Serum Testosterone group (7.9 $+/-1.1 \%$ ) when compared to the normal Testosterone Group $(7.5+/-0.9 \%)$. Increased hsCRP levels were seen in the Low Serum Testosterone group $(3.2+/-1.0 \mathrm{mg} / \mathrm{dL})$ than in the normal Testosterone Group $(1.9+/-0.8 \mathrm{mg} / \mathrm{dL})$. CIMT in the Low Serum Testosterone group $(0.82+/-0.1 \mathrm{~mm})$ was significantly more than the normal Testosterone Group $(0.65$ + - $0.1 \mathrm{~mm}$ ). IHD was more frequent in the Low Serum Testosterone group (29\%) versus the normal Testosterone Group (20\%). Hence, to conclude, a Low Serum Testosterone can serve as an adverse prognostic marker contributing to an increased atherosclerotic burden. Serum Testosterone should be screened for in all newly diagnosed patients of Type 2 Diabetes Mellitus.

\section{REFERENCES}

[1] American Diabetes Association. Diagnosis and classification of diabetes mellitus. Diabetes Care 2014;37(1):S81-90.

[2] Quantia CRP US. Available from: http://www.tulipgroup.com/Tulip_New/html/pack_i nserts/Quantia\%20CRP\%20US.pdf

[3] Serum testosterone ELISA ALPCO. Available from: https://www.alpco.com/store/serum-testosteroneelisa.html.

[4] El Saghier EOA, Shebl SE, Fawzy OA, et al. Androgen deficiency and erectile dysfunction in patients with type 2 diabetes. Clin Med Insights Endocrinol Diabetes 2015;8:55-62.

[5] Barrett-Connor E. Lower endogenous androgen levels and dyslipidemia in men with non-insulin-dependent diabetes mellitus. Ann Intern Med 1992;117(10):80711.
[6] Al Hayek AA, Khawaja NM, Khader YS, et al. The prevalence of hypogonadism among diabetic and nondiabetic men in Jordan. J Diabetes Complications 2014;28(2):135-40.

[7] Kapoor D, Aldred H, Clark S, et al. Clinical and biochemical assessment of hypogonadism in men with type 2 diabetes: correlations with bioavailable testosterone and visceral adiposity. Diabetes Care 2007;30(4):911-7.

[8] Al Hayek AA, Khader YS, Jafal S, et al. Prevalence of low testosterone levels in men with type 2 diabetes mellitus: a cross-sectional study. J Fam Community Med 2013;20(3):179-86.

[9] Roudebush WE, Witt MA, Kort HI, et al. Men with high body mass index values present with lower serum testosterone levels. Fertil Steril 2005;84(1):74.

[10] Simon D, Charles MA, Nahoul K, et al. Association between plasma total testosterone and cardiovascular risk factors in healthy adult men: the telecom study. J Clin Endocrinol Metab 1997;82(2):682-5.

[11] Gannage-Yared MH, Chedid R, Abs L. Relation between androgens and cardiovascular risk factors in a young population. Clin Endocrinol (Oxf) 2011;74(6):720-5.

[12] Schneider HJ, Sievers C, Klotsche J, et al. Prevalence of low male testosterone levels in primary care in Germany: cross-sectional results from the DETECT study. Clin Endocrinol (Oxf) 2009;70(3):446-54.

[13] Farias JM, Tinetti M, Khoury M, et al. Low testosterone concentration and atherosclerotic disease markers in male patients with type 2 diabetes. J Clin Endocrinol Metab 2014;99(12):4698-703.

[14] Soisson V, Brailly-Tabard S, Empana JP, et al. Low plasma testosterone and elevated carotid intimamedia thickness: importance of low-grade inflammation in elderly men. Atherosclerosis 2012;223(1):244-9.

[15] English KM, Mandour 0, Steeds RP, et al. Men with coronary artery disease have lower levels of androgens than men with normal coronary angiograms. Eur Heart J 2000;21(11):890-4.

[16] Jones RD, Nettleship JE, Kapoor D, et al. Testosterone and atherosclerosis in aging men: purported association and clinical implications. Am J Cardiovasc Drugs Drugs Devices Interv 2005;5(3):141-54.

[17] Rosano GM, Sheiban I, Massaro R, et al. Low testosterone levels are associated with coronary artery disease in male patients with angina. Int J Impot Res 2007;19(2):176-82.

[18] Laughlin GA, Barrett-Connor E, Bergstrom J. Low serum testosterone and mortality in older men. J Clin Endocrinol Metab 2008;93(1):68-75.

[19] Hackett GI, Cole NS, Deshpande AA, et al. Biochemical hypogonadism and type 2 diabetes in primary care. $\mathrm{Br}$ J Diabetes Vasc Dis 2009;9(5):226-31.

[20] Fukui M, Tanaka M, Hasegawa G, et al. Association between serum bioavailable testosterone concentration and the ratio of glycated albumin to glycated hemoglobin in men with type 2 diabetes. Diabetes Care 2008;31(3):397-401. 